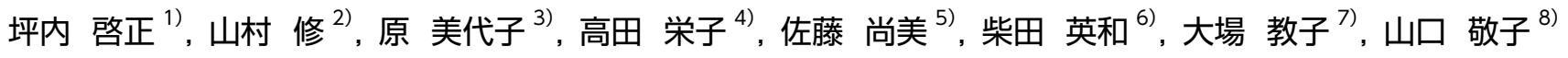 \\ 1) 福井県済生会病院放射線技術部 \\ 2) 福井大学医学部地域医療推進講座 \\ 3) 福井県済生会病院看護部 \\ 4) 福井県済生会病院検査部 \\ 5) 公立穴水総合病院検査部 \\ 6) 福井循環器病院放射線技術科 \\ 7) 珠洲市総合病院検查部 \\ 8) 奈良県総合医療センター中央臨床検査部
}

\title{
Lower limb venous ultrasonographic examination for possible deep venous thrombosis among evacuees after the large-scale flood and landslide disaster in the Kii Peninsula
}

\author{
Hiromasa TSUBOUCHI ${ }^{1)}$, Osamu YAMAMURA ${ }^{2)}$, Miyoko HARA $^{3)}$, Eiko TAKADA ${ }^{4)}$, Naomi SATOU ${ }^{5)}$, \\ Hidekazu SHIBATA ${ }^{6}$, Noriko OOBA $^{7)}$, Keiko YAMAGUCHI ${ }^{8)}$ \\ 1) Department of Radiotechnology, Fukuiken Saiseikai Hospital \\ 2) Department of Community Medicine, University of Fukui Hospital \\ 3) Nursing Department, Fukuiken Saiseikai Hospital \\ 4) Department of Clinical Laboratory, Fukuiken Saiseikai Hospital \\ 5) Department of Clinical Laboratory, Anamizu General Hospital \\ 6) Department of Radiotechnology, Fukui CardioVascular Center \\ 7) Department of Clinical Laboratory, Suzu General Hospital \\ ${ }^{8)}$ Department of Central Clinical Laboratory, Nara Prefecture General Medical Center
}

\begin{abstract}
Introduction: On August 25, 2011, Typhoon No.12 hit the village of Kitamata in Nosegawa, Nara Prefecture, Japan. Residents were forced to seek long-term shelter in evacuation facilities because of sediment runoff in the district. Authorities feared that these residents might have developed deep venous thrombosis (DVT). Thus, DVT screening was conducted among the residents in order to examine factors related to the occurrence of DVT among residents in landslide-affected areas.

Methods: Among the residents, 33 were eligible for DVT screening. A portable ultrasonography equipment was used to explore for possible DVT in the soleal vein on both sides and measure its maximum diameter.

Results: Of the 33 subjects, 3 (9.1\%) had DVT, out of which 2 had fresh thrombi. On ultrasonography, all 3 patients $(100 \%)$ had soleal vein extension of greater than $8 \mathrm{~mm}$ and tested positive for DVT. However, no significant difference in soleal vein extension was found in comparison with the 11 patients $(36.7 \%)$ who tested negative for DVT ( $p=0.0667)$.

Conclusion: In the residents in this study who stayed in evacuation facilities over a long period after the landslide in their area, fresh DVT was confirmed. In addition, we identified soleal vein extension as a possible factor for the occurrence of DVT.
\end{abstract}

Keywords: sediment disaster, disaster-related disease, venous ultrasonography, soleal vein dilatation, deep venous thrombosis

(Received April 8, 2016; Accepted June 7, 2016) 


\section{はじめに}

2011 年 8 月 25 日に発生した台風 12 号により, 8 月 31 日から9月 4 日までの総雨量は, 紀伊半島を中心に 広い範囲で $1,000 \mathrm{~m}$ を超え, 記録的な大雨をもたらし た ${ }^{1)}$. この大雨により大規模な斜面崩壊が多数発生し, 崩壊土砂流出による道路の決壊, 住宅全壊, 浸水などの 被害が発生した ${ }^{1)}$ 。奈良県野迫川村北股地区では，斜面 崩壊による土砂崩れが発生し多くの民家が倒壊したこと から ${ }^{2)}$, 被災者は長期間の避難所生活を余儀なくされた。 野迫川村北股地区の避難所には人口 530 名 ${ }^{3)}$ のうち最大 239 名の住民が殺到し ${ }^{4}$ ， 深部静脈血栓症（deep venous thrombosis：DVT）の発生が危惧された。過去の研究 により地震災害による避難所生活では DVT の検出率が 高いことが報告されているが5)，土砂低害避難所生活に おけるDVTの発生頻度は不明である。今回，われわれ は奈良県野迫川村北股地区被災地の避難所と仮設住宅に おいて DVT 検診活動を実施し, 土砂災害被災地における DVT 検出率と関連要因について検討したので報告する.

\section{対象}

奈良県野迫川村北股地区の避難所と仮設住宅におい て, 発災 5 週目（2011 年 10 月，第 1 回）と発災 27 週 目（2012 年 3 月，第 2 回）にDVT検出を目的とした 下肢静脈エコー検診を実施した。対象は被災住民で，第 1 回検診では 20 名（避難所，男性：女性 $=9: 11$, 平 均年齢 $61.6 \pm 15.0$ 歳), 第 2 回検診で 25 名（仮設住宅, 男性：女性 $=7: 18$, 平均年齢 $71.6 \pm 8.7$ 歳）が受診 した。そのうち再検者は 12 名であった。

\section{方法}

事前に静脈血栓塞栓症予防を目的としたエコー検診の 案内ポスターを野迫川村役場に送付し，下肢静脈エコー 検査の受検を促した。当日に検診を行う目的，重要性を 説明し, 同意書を取得した。検査前の問診において年齢, 性別, 下肢症状の有無, 発災後の生活環境, 基礎疾患, 生活習慣（喫煙・飲酒・運動習慣）について聴取した。 その後, 携帯用エコー機器を避難所の集会場に持ち込み, 医師，臨床検查技師，診療放射線技師で下肢静脈エコー 検査を行った。超音波機器はSonoSite NanoMaxx （7.5MHzリニアプローブ）を使用した. エコー検診では， オープンスペースで検査を行うことからプライバシーが 保てないこと，また呂らの報告 ${ }^{6)} に よ り$ 院外発生肺血栓 塞栓症の DVT は下腿静脈から多く発生していることか ら，大腿部の症状がある場合を除いて，ヒラメ筋静脈を 中心とした膝窩静脈以遠の下腿静脈を検査した。検査は 座位で行い, B モードによる血栓エコーの有無, 圧迫法,
カラードプラ法による DVT の有無, 性状, 静脈拡張に ついて診断した。静脈拡張については，新潟県中越大震 災被災地住民に対する深部静脈血栓症（DVT）/肺血栓 塞栓症（PE）診断，治療ガイドラインを参考に， $8 \mathrm{~mm}$ 以上を拡張とした ${ }^{7)}$ 。血栓陽性者には診療情報提供書を 作成し，かかりつけ医および近医受診を促した。

\section{統計解析}

年齢は平均值土標準偏差で表記した，名義変数は，例 数および各群における頻度（\%）にて表記した。統計解 析は StatFlex Ver.6 (株式会社アーテック社製) を使用し， 2 群間の比較には $\mathrm{t}$ 検定, $\chi^{2}$ 検定 (Yates 連続補正も含む) もしくは Fisherの直接確率計算法を使用した. $p<0.05$ を統計学的に有意とした．DVTの検出頻度では再検者 の 2 回目検診結果を除いた 33 名で解析し, 避難所と仮 設住宅での比較では再検者の 2 回目検診結果を含めた 45 名で解析した。

\section{結果}

避難所と仮設住宅での検診において再検者の 2 回目 検診を除いた 33 名の被災者の DVT 検出率は3名 （9.1\%）であった。再検者の 2 回目検診結果を含めた各 週の DVT 検出率は，発災 5 週目で 2 名 $(10 \%)$ ，発災 27 週目で 2 名（8％) であった。検診受検者背景の結果 を Table 1 に示す。年齢, 性別, 基礎疾患, 生活習慣, 避難所生活背景において両間群に有意差は認めなかっ た。避難所では全例，床下および畳の上で仕切りのない 雑魚寝による集団就寝を繰り返していた。 ヒラメ筋静脈 拡張は，DVT 陽性群 3 例 (100\%) と DVT 陰性群 11 例 $(36.7 \%)$ の間に有意差は認めなかった $(p=0.0667)$. 血栓陽性者の詳細を Table 2 に示す。血栓陽性者は，全 例ヒラメ筋静脈に血栓を認め, そのうち 2 例は新鮮血 栓であった。避難所別受検者背景を Table 3 に示す。年 齢において避難所群の平均年齢 $61.6 \pm 15.0$ 歳と仮設住 宅群の平均年齢 $71.6 \pm 8.7$ 歳と比較して年齢が有意に 高值であった $(p=0.0073)$. そのほか, 性別, 基礎疾患, 生活習慣，避難所生活背景，既往歴，超音波所見におい て両群に有意差は認めなかった。代表例を提示する.

\section{Case $1: 78$ 歳女性}

既往歴：特記すべきことなし.

避難生活：雑魚寝で就寝を繰り返し，寝不足のため睡眠 薬を服薬していた。

現病歴と経過：第 1 回検診を受検した。問診では下肢 症状を認めなかった。エコー検査では，ヒラメ筋静脈に 最大径 $9 \mathrm{~mm}$ の拡張を認め, 右ヒラメ筋静脈に限局性の 充満した低輝度エコー血栓を認めた（Fig.1a）。血栓は 
Table 1 Examinees' background characteristics

\begin{tabular}{|c|c|c|c|}
\hline \multirow{2}{*}{ Background factor } & \multicolumn{2}{|c|}{ DVT } & \multirow{2}{*}{$p$ value } \\
\hline & Present $(n=3)$ & Absent $(n=30)$ & \\
\hline Age (years) & $74.7 \pm 6.7$ & $65.9 \pm 14.6$ & 0.3175 \\
\hline Sex (male) & $1(33.3)$ & $12(40.0)$ & 1.000 \\
\hline \multicolumn{4}{|l|}{ Disease } \\
\hline Hypertension & $1(33.3)$ & 14 (46.7) & 1.000 \\
\hline Diabetes & $1(33.3)$ & $2(6.7)$ & 0.2559 \\
\hline Dyslipidemia & $1(33.3)$ & $8(26.7)$ & 1.000 \\
\hline \multicolumn{4}{|l|}{ Lifestyle habit } \\
\hline Current smoking & 0 & $5(16.7)$ & 1.000 \\
\hline Drinking & 0 & $8(26.7)$ & 0.5601 \\
\hline Daily exercise & $2(66.7)$ & $9(30.0)$ & 0.5343 \\
\hline \multicolumn{4}{|l|}{ Shelter life } \\
\hline Lack of sleep & $2(66.7)$ & $11(36.7)$ & 0.5473 \\
\hline Sleeping pill use & $2(66.7)$ & $11(36.7)$ & 0.5473 \\
\hline Sleeping in a vehicle & 0 & $2(6.7)$ & 1.000 \\
\hline Reduced urination & 0 & $3(10.0)$ & 1.000 \\
\hline Lower limb symptoms & 0 & $11(36.7)$ & 0.5343 \\
\hline \multicolumn{4}{|l|}{ Medical history } \\
\hline Heart disease & 0 & $3(10.0)$ & 1.000 \\
\hline Malignant tumor & $1(33.3)$ & 0 & 0.0909 \\
\hline \multicolumn{4}{|l|}{ Ultrasonographic findings } \\
\hline Maximum diameter of the soleal vein & $8.8 \pm 0.6$ & $7.4 \pm 1.9$ & 0.2041 \\
\hline Soleal vein dilatation $(\geq 8 \mathrm{~mm})$ & $3(100)$ & $11(36.7)$ & 0.0667 \\
\hline
\end{tabular}

Data are mean \pm SD or $\mathrm{n}$ (\% of group with or without DVT). DVT: deep venous thrombosis

Table 2 Characteristics of the subjects with DVT

\begin{tabular}{|c|c|c|c|c|c|}
\hline Case & $\begin{array}{c}\text { Age } \\
\text { (years) }\end{array}$ & Sex & $\begin{array}{l}\text { Maximum } \\
\text { vein } \\
\text { diameter } \\
(\mathrm{mm})\end{array}$ & $\begin{array}{c}\text { Thrombus } \\
\text { detection site }\end{array}$ & $\begin{array}{l}\text { Thrombotic } \\
\text { properties }\end{array}$ \\
\hline 1 & 78 & Female & 9.0 & Right soleal vein & Fresh \\
\hline 2 & 67 & Female & 8.2 & Left soleal vein & Fresh \\
\hline 3 & 79 & Male & 9.3 & Left soleal vein & Calcification \\
\hline
\end{tabular}

DVT: deep venous thrombosis

Table 3 Background of the examinees from the shelter

\begin{tabular}{|c|c|c|c|}
\hline Background factor & $\begin{array}{l}\text { Shelter } \\
\text { group } \\
(n=20)\end{array}$ & $\begin{array}{c}\text { Temporary } \\
\text { housing group } \\
(\mathbf{n}=25)\end{array}$ & $p$ value \\
\hline Age (years) & $61.6 \pm 15.0$ & $71.6 \pm 8.7$ & $0.0073^{*}$ \\
\hline Sex (male) & $9(45.0)$ & $7(28.0)$ & 0.3841 \\
\hline \multicolumn{4}{|l|}{ Disease } \\
\hline Hypertension & $7(35.0)$ & $11(44.0)$ & 0.7595 \\
\hline Diabetes & $3(15.0)$ & $2(8.0)$ & 0.6423 \\
\hline Dyslipidemia & $4(20.0)$ & $9(36.0)$ & 0.3977 \\
\hline \multicolumn{4}{|l|}{ Lifestyle habit } \\
\hline Current smoking & $5(25.0)$ & $4(16.0)$ & 0.7095 \\
\hline Drinking & $5(25.0)$ & $6(24.0)$ & 1.0000 \\
\hline Daily exercise & $4(20.0)$ & $9(36.0)$ & 0.3977 \\
\hline \multicolumn{4}{|l|}{ Shelter life } \\
\hline Lack of sleep & $9(45.0)$ & $8(32.0)$ & 0.5590 \\
\hline Sleeping pill use & $7(35.0)$ & $10(40.0)$ & 0.9726 \\
\hline Sleeping in a vehicle & $1(5.0)$ & $2(8.0)$ & 1.0000 \\
\hline Reduced urination & 0 & $4(16.0)$ & 0.1174 \\
\hline Lower limb symptoms & $4(20.0)$ & $10(40.0)$ & 0.2644 \\
\hline \multicolumn{4}{|l|}{ Medical history } \\
\hline Heart disease & $2(10.0)$ & $1(4.0)$ & 0.5772 \\
\hline Malignant tumor & 0 & $1(4.0)$ & 1.0000 \\
\hline \multicolumn{4}{|l|}{ Ultrasonographic findings } \\
\hline Maximum diameter of the soleal vein & $7.4 \pm 1.9$ & $7.1 \pm 1.8$ & 0.5336 \\
\hline Soleal vein dilatation $(\geq 8 \mathrm{~mm})$ & $7(35.0)$ & $9(36.0)$ & 0.8074 \\
\hline DVT & $2(10.0)$ & $2(8.0)$ & 1.0000 \\
\hline
\end{tabular}

Data are mean \pm SD or $\mathrm{n}\left(\%\right.$ of group with or without DVT). ${ }^{*} p<0.01$. DVT: deep venous thrombosis
管腔内に充満し，圧迫法により変形するも のの完全には圧縮されなかった，以上から 新鮮血栓と診断した. 近医受診を促したが, 受診せず経過した。第 2 回検診において, 前回と同部位の右ヒラメ筋静脈に浮遊状血 栓として残存していた（Fig.1b）.

\section{Case $2: 67$ 歳女性}

既往歴：特記すべきことなし.

避難生活: 杂隹魚寝で就寝を繰り返していた. 現病歴と経過：第 1 回検診を受検した。問 診では下肢症状を認めなかった。エコー検 査では，ヒラメ筋静脈に最大径 $8.2 \mathrm{~mm}$ の 拡張を認めた。左ヒラメ筋静脈には充満し た低輝度エコーの血栓を認め，圧迫法では 血栓は完全に圧縮されなかった（Fig.2）. 以上より新鮮血栓と診断した。検査後, 近 医を受診しワルファリン内服で経過した。 第 2 回 DVT 検診において, 静脈径は最大 径 $6.2 \mathrm{~mm}$ と前回に比べ縮小し, 血栓が消 失しているのを確認した。

\section{考察}

地震，津波による大きな自然災害では， 多くの被災者が長期間の避難所生活を余儀 なくされる。わが国の被災地では，地域の 学校の体育館や公民館などに避難所が設置 される場合が多い ${ }^{8)}$ 。しかしその避難所の 

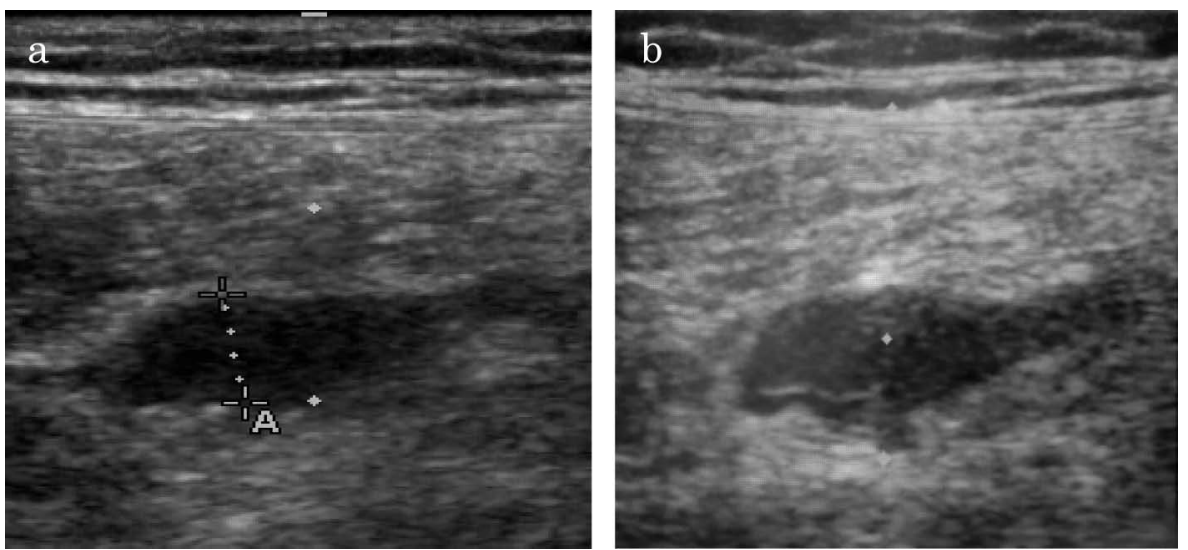

Fig.1 Case 1

Longitudinal venous ultrasonographic image. (a) Thrombus in the vein is exhibiting a lowbrightness echo. (b) The thrombus remains floating with marginal high echo band in the second screening.

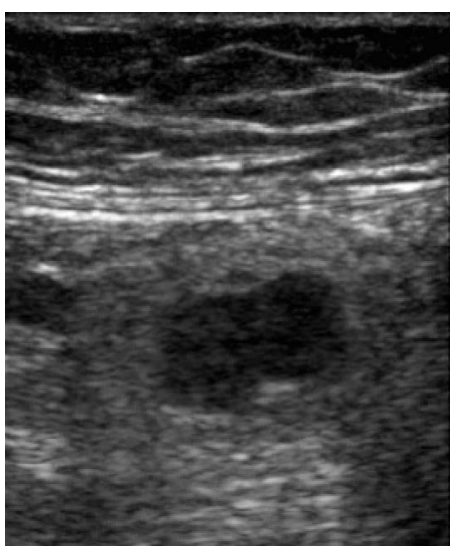

Fig. 2 Case 2

Longitudinal venous ultrasonographic image. Thrombus in the vein is exhibiting a low-brightness echo.
多くは，環境衛生的に劣悪であり，生活環境の悪化，ス トレスなどにより, 消化管疾患, 呼吸器疾患, 循環器疾 患など震災後関連疾患発症の温床となる ${ }^{9}$ 。2 2004 年の 新潟中越地震では，車中泊避難者に肺塞栓症死亡例が報 告され, 静脈血栓塞栓症が震災関連疾患の一つとして注 目された ${ }^{10)}$ 。その後の 2007 年の能登半島地震, 2007 年の新潟中越沖地震, 2008 年の岩手 ·宮城内陸地震の 避難所において, 肺塞栓症の主な原因である DVT が下 肢静脈エコーによって高頻度に検出された ${ }^{11-14)}$ (Table 4)。 また東日本大震災では下肢 DVT が塞栓源となりう る奇異性脳塞栓症例が, 発災後 6 力月から 12 力月まで の間で有意に増加したと報告された ${ }^{15)}$ ，野迫川村北股 地区では 9 月 4 日に土砂崩れが発生し，一時的に最大 239 名の被災者が避難所に殺到した。 その後, 避難指示, 警戒区域が指定され 50 名の被災者が長期避難者となっ た ${ }^{4)}$ 。野迫川村は標高 $840 \mathrm{~m}$ の山間部に位置し, 交通ア クセスも不便で，娛楽施設，食料杂晔貨店，基幹医療機関 は周辺になく，高齢者の割合が高い地域である，東日本 大震災被災地の仙台市の避難所における発災 1 力月後 の調査では, 震災以前は生活機能が自立していた高齢者 の $62.7 \%$ が歩行困難などをきたしていることが報告さ れ ${ }^{16)}$, 野迫川村北股地区の避難所においても生活機能 低下によるDVT の発症が懸念された。われわれの調査 では，野迫川村北股地区の DVT 検出頻度は $9.1 \%$ であ り，新潟県阿賀町の対照地域（非被災地）で検出された DVT 検出率（1.8\%）に比べて高かった ${ }^{17)}$ 。過去の新 潟中越地震, 能登半島地震, 新潟中越沖地震では, 発災 後（2〜4 週）時間経過とともにDVT 検出率は低下し ていたのに対し，野迫川村北股避難所では発災後 5 週 を経過していたが，新鮮血栓は $10 \%$ に認められ，避難 所生活により DVT が誘発された可能性が推測された。 雑魚寝の避難所生活では 5 10\%の DVT が認められ
たことが報告されており ${ }^{18)}$ ，古くは 1940 年のロンドン 空襲時に，地下鉄構内で雑魚寝による就寝を繰り返した 被災者に肺塞栓症が多発したことが報告されている ${ }^{19)}$. 高齢者は雑魚寝では床から起き上がりにくいため活動低 下による血流停滞が影響すること ${ }^{18)}$ ，人の足音や振動 が直に伝わってくることから寝不足となり，震災後の疲 労の蓄積から交感神経刺激となることで, 血栓形成が促 進される ${ }^{20)}$ ．また，睡眠薬を服用することで筋肉弛緩 による静脈血流停滞が起こり，結果的に血栓形成傾向が 強まる可能性がある，新潟中越地震被災者では睡眠薬を 服用した被災者にDVT が多い傾向が認められた ${ }^{211}$ ，野 迫川村北股の受検者でも寝不足 $(39.9 \%)$ ，睡眠薬服用 （39.9\%）が多く，全ての受検者が床下（フローリング） や畳で雑魚寝生活を繰り返していた，寝不足による精神・ 肉体的ストレス，睡眠薬服用による筋肉弛緩，雑魚寝生 活による活動低下などの因子が重なり，血流停滞や血液 凝固能立進を惹起することで，発災後 5 週を経過して もDVT 検出率が高かったものと推測される，土砂災害 における避難所生活も，地震災害と同様に，血栓イベン トのリスクが増大する可能性が示唆された。

ヒラメ筋静脈に限局した DVT から症候性肺塞栓症が 誘発されたこと ${ }^{22)}$, 院外発症の致死的肺塞栓症の原因 はヒラメ筋静脈血栓の中枢進展であることが報告さ $れ^{6}$ ，災害時の下肢静脈エコーによるヒラメ筋静脈の DVT 検索は重用視されている。 Ohgi らは，ヒラメ筋静 脈径が $7 \mathrm{~mm}$ 以上で突発性 DVT が数多く検出されたこ とから，ヒラメ筋静脈の拡張が血栓形成に関与すると結 論づけた ${ }^{222}$ 。また, 前田らは東日本大震災被災地の DVT 検診において, ヒラメ筋静脈 $9 \mathrm{~mm}$ 以上の拡張陽 性群では, 陰性群と比較し DVT の検出率が有意に高く, DVT 発生のリスクを把握するのに有用であったと報告 した ${ }^{23)}$ ，今回われわれの調査でも，DVT 陽性例は全例 
Table 4 Comparison of deep venous thrombosis detection frequency after past disasters in Japan*

\begin{tabular}{lccc}
\hline \multicolumn{1}{c}{ Earthquake } & $\begin{array}{c}\text { Post- } \\
\text { disaster } \\
\text { (weeks) }\end{array}$ & $\begin{array}{c}\text { DVT } \\
\text { detection } \\
\text { frequency }\end{array}$ & $\begin{array}{c}\text { Maximum No. } \\
\text { of evacuees }\end{array}$ \\
\hline $\begin{array}{l}\text { 2004, The Mid Niigata } \\
\text { Prefecture Earthquake }\end{array}$ & $1-2$ & $30.4 \%$ & $\begin{array}{l}100,000 \\
\text { (Sleeping in a } \\
\text { vehicle 10,000) }\end{array}$ \\
& 4 & $12 \%$ & 1,200 \\
$\begin{array}{l}\text { 2007, The Noto Hanto } \\
\text { Earthquake }\end{array}$ & 2 & $10.6 \%$ & \\
2007, The Niigataken & 1 & $6.9 \%$ & 12,000 \\
$\begin{array}{l}\text { Chuetsu-oki Earth- } \\
\text { quake }\end{array}$ & 2 & $3.3 \%$ & \\
$\begin{array}{l}\text { 2008, The Iwate-Miyagi } \\
\text { Nairiku Earthquake }\end{array}$ & 1 & $8.2 \%$ & 256 \\
$\begin{array}{l}\text { 2011, Kii Peninsula } \\
\text { large-scale flood (the }\end{array}$ & $2-3$ & $10.7 \%$ & \\
present study) & 5 & $10 \%$ & 239 \\
\hline
\end{tabular}

${ }^{*}$ Modified quote from the Refs. 10-14. DVT: deep venous thrombosis

$8 \mathrm{~mm}$ 以上と静脈拡張しており，避難所生活での活動低 下による血流停滞が関係しているものと考える，災害時 の下肢静脈エコーにおいて, 静脈拡張を観察することは DVT 検出の手掛かりとなることから，検診時の計測は 必須であると考える，本症例では，ヒラメ筋静脈に新鮮 血栓が認められたが, 早期に限局的な DVTを検出し, 近医に診察するよう促したことで，将来発生する可能性 のある肺塞栓症や奇異性脳塞栓症を未然に防ぐことが期 待される.

\section{結語}

土砂災害における長期避難所生活においても，長期間 にわたって避難所が継続する場合，新鮮 DVTが検出さ れることが確認された。また，ヒラメ筋静脈拡張は DVT 発生の因子となる可能性が示された。

\section{謝辞}

紀伊半島大水害の災害医療活動は，野迫川村役場の協 力のもと行われた．現地では野迫川村役場保健師 俊成 輝子様にご協力いただいた。この場を㧍借りし深くお礼 申しあげたい

利益相反：著者全員が，本論文に関する研究に関して 利益相反なし

倫理規定：本研究は, 福井県済生会病院倫理審査委員 会の承認を得ている。

本論文の要旨は第 18 回日本栓子検出と治療学会 （2015 年 9 月，栃木）にて発表した.

\section{文献}

1）奈良県防災総括室:紀伊半島大水害の記録（インターネット), 奈良県, 2012，14p.（閲覧日 2012-10-01）, http://www.pref. nara.jp/item/90211.htm

2）木田悠一:野迫川村北股砂防事業について（インターネット）。 平成 26 年度奈良県技術研究発表会 2014; 9: 1-4.（閲覧日 2015-07-01), http://www.pref.nara.jp/secure/133113/9.kida_ ronbun.pdf

3）奈良県：住民基本台帳及び外国人登録に基づく人口による年 齢別人口調查結果平成 23 年 10 月 1 日現在 (インターネット). 奈良県：年齢別人口調査.（閲覧日 2015-07-01）, http:// www.pref.nara.jp/34374.html

4）奈良県防災統括室：報道資料，台風 12 号に関する被害状況 等について 第 14 報（平成 23 年 9 月 4 日 $22: 00$ 発表）（イ ンターネット)。奈良県：紀伊半島大水害に関する情報。（閲 覧日 2015-07-01), http://www.pref.nara.jp/dd.aspx?moduleid $=48720 \&$ pfromid $=100 \#$ moduleid 48720

5) 榛沢和彦：特殊病態での凝固・線溶異常 ; 災害. 救急医学 2011; 35: 1857-1864.

6) 呂彩子, 谷藤隆信, 影山則正, 他：院外発症の肺動脈血栓塞 栓症による突然死 51 例の病理形態学的検討. 脈管学 2003; 43: 627-632.

7）布施一郎，相澤義房，林純一，他：新潟県中越大震災被災地 住民に対する深部静脈血栓症（DVT）/肺血栓塞栓症（PE） 診断，治療ガイドライン． 新潟県，2006， p.5-24.

8）藤田俊夫：内科医のための災害医療活動；医療支援編（避難 所編）。日内会誌 2010; 99: 2604-2606.

9）上田耕蔵, 石川靖二, 安川忠通: 震災後関連死亡とその対策. 医事新報 1996; 3776: 40-44.

10）榛沢和彦：中越地震における車中泊者の肺・静脈血栓塞栓症 の危険性について一車中泊者のエコー診療から一. Ther Res 2006; 26: 1207-1212.

11）寺上貴子, 大場教子, 森下英理子, 他：2007 年能登半島地 震に打ける深部静脈血栓症の発症状況．臨病理 2009; 57: 411-416.

12）坪内啓正，山村修，木村裕治：能登半島地震被災地に扔ける 避難状況と下肢静脈エコー所見の比較。第 10 回日本栓子検 出と治療学会抄録集 2007, SPI-3, 108 。

13）榛沢和彦, 岡本竹司, 佐藤浩一, 他：中越沖地震に打ける DVT頻度. Ther Res 2008; 29: 641-643.

14）柴田宗一，菊田寿，住吉剛忠，他：『チーム栗原』一岩手 · 宮城内陸地震に打ける静脈血栓塞栓症予防活動一。臟 2010; 42: 473-480.

15) Itabashi R, Furui E, Sato S, et al.: Incidence of cardioembolic stroke including paradoxical brain embolism in patients with acute ischemic stroke before and after the Great East Japan Earthquake. Cerebrovasc Dis 2014; 37: 431-437.

16) Okawa Y, Takimura K: Decline of Functioning in Elderly Persons two Months after the Great Earthquake in Japan. Newsletter on the WHO-FIC 2011; 9(2): 10.

17）榛沢和彦, 林純一, 田辺直仁, 他：新潟県中越地震被災地に 打ける深部静脈血栓症一対照地域検査との比較一. Ther Res 2007; 28: 1126-1128.

18）榛沢和彦：福島県外避難者の避難所におけるDVT頻度と高血 圧頻度：避難環境との関係。血栓と循環 2012; 20: 53-61.

19) Simpson K: Shelter deaths from pulmonary embolism. Lancet 1940; $2: 744$.

20）榛沢和彦：エコノミークラス症候群とその予防．血圧 2011; 18: 740-745.

21）田中純太, 榛沢和彦, 鈴木栄一：新潟県中越地震における深 部静脈血栓症. 総合臨床 2006; 55: 1813-1816.

22) Ohgi $S$, Tachibana M, Ikebuchi M, et al.: Pulmonary embolism in patients with isolated soleal vein thrombosis. Angiology 1998; 49: 759-764.

23）前田文江，山村修，植田信策，他：被災地検診活動から得ら れたヒラメ静脈径拡張の関連要因について。医学検査 2016; 65: 25-31. 